\title{
THE SYSTEM OF PUBLIC TRADE SERVICE IN KHARKIV REGION: PROBLEMS AND DIRECTIONS OF IMPROVEMENT
}

\author{
Pavlo KOBYLIN \\ V.N. Karazin Kharkiv National University, Ukraine \\ kobilin333@gmail.com
}

\begin{abstract}
The system of the public trade service is an important component of the national economy, satisfying the material and spiritual needs of people and stimulating in this way regional socio-economic development. However, in Ukraine, this sector has certain development problems to be solved. The aim of the article is identification of territorial development problems of the system of public trade service and working out scientifically justified recommendations for improvement of this system from the perspective of human geography. A method of the component analysis of the developmental vector was applied to characterize the dynamic development of the system of public trade service based on calculations of sum codes of the time derivatives of the research parameters. After grouping of the studied indicators, 5 groups of indicators were distinguished based on prevailing trend of the dynamics of parameters within districts and cities of regional subordination of Kharkiv region and average dynamic within the region on the whole. The distinguished groups of indicators allow identifying level of the problems (regional/local) and determine priorities in their solving.
\end{abstract}

Key words: component analisis, system of the public trade service, region, code of the time derivative, district, city, development problems.

DOI: https://doi.org/10.17721/2413-7154/2017.77.33-40

UDC: 911.3

\section{ПРОБЛЕМИ ТА НАПРЯМИ УДОСКОНАЛЕННЯ СИСТЕМИ ТОРГОВЕЛЬНОГО ОБСЛУГОВУВАННЯ ХАРКІВСЬКОЇ ОБЛАСТІ}

\author{
Павло КОБИлІн \\ Харківський начіональний університет імені В.Н. Каразіна, Україна \\ kobilin333@gmail.com
}

\begin{abstract}
Анотація: Система торговельного обслуговування населення $\epsilon$ важливим компонентом народногосподарського комплексу, яка задовольняє матеріальні і духовні потреби людей, стимулює соціально-економічний розвиток. Проте ця сфера діяльності має певні проблеми розвитку, які потребують вирішення. Метою публікації $\epsilon$ виявлення територіальних проблем розвитку системи торговельного обслуговування населення та розробка науковообгрунтованих рекомендацій з удосконалення цієї системи з позицій суспільної географії. Для характеристики динаміки розвитку системи торговельного обслуговування населення Харківської області використано метод компонентного аналізу вектору розвитку, в основу якого покладено розрахунки суми кодів часових похідних за досліджуваними параметрами. На основі виявлення переважаючої тенденції розвитку окремих параметрів у розрізі районів та міст обласного підпорядкування Харківської області і середньої динаміки по регіону в цілому проведено групування досліджуваних показників, зокрема виділено 5 груп параметрів. Виділені групи параметрів дозволяють ідентифікувати проблеми (регіональні/локальні) та виявити пріоритетність у їх вирішенні.
\end{abstract}

Ключові слова: компонентний аналіз, система торговельного обслуговування населення, регіон, код часової похідної, район, місто, проблеми розвитку.

DOI: https://doi.org/10.17721/2413-7154/2017.77.33-40

Удк: 911.3

Актуальність. Центральне місце у суспільстві посідає соціум, який, генеруючи потреби, стає стимулом суспільного розвитку. Задоволення соціальних потреб відбувається через сферу послуг та виробництво. Враховуючи широкий спектр потреб людини, сфера послуг налічує велику кількість галузей. Однією з таких виступає система торговельного обслуговування населення, яка задовольняє різні матеріальні і духовні потреби людей, потреби у товарах, торгових послугах. Розвиток торгівлі свідчить про ефективність

державної політики, впровадження соціальноекономічних реформ, оскільки створення умов для задоволення потреб людей є головним пріоритетом державної соціальної політики. Ця сфера впливає на організацію побуту людей, зайнятість населення, сприяє збільшенню вільного часу.

Функціонування будь-якої сфери господарського комплексу характеризується певними проблемами, враховуючи, що система торговельного обслуговування населення дуже чутлива до споживчих настроїв населення, кризових явищ в країні. Проблеми в торгівлі мають комплексний характер, тобто їх аналіз потребує спеціальних правових, 
фінансових, економічних та інших досліджень. Проблеми у сфері торгівлі, ресторанного господарства також мають територіальний характер, обумовлений нерівномірним розподілом закладів торгівлі, різною динамікою зміни окремих параметрів, що характеризують діяльність сфер, в адміністративнотериторіальних одиницях регіону. Виявлення таких проблем потребує використання просторово-часового аналізу, який має сформовану методологічну основу у суспільній географії.

Попередні дослідження. Суспільно-географічні аспекти торговельної діяльності регіону розглядалися у роботах М.Григор'євої [5], В.Дорошенко [6], Е.Калмуської [10], О.Мамчур [14], І.Осіпчук [17], І.Уколової [25], Л.Шенцевої [27], з позицій регіональної економіки - у роботах Т.Білоконя [2], О.Головні [4], Є.Колосінського [11], М.Мальської [13], В.Пахомова [19], С.Дудек-Манковської (S. DudekMańkowska) [30], П.Гуімарес (P. Guimaraes) [32], Д. Шиманської, С. Сроди-Муравської (D. Szymańska, S. Środa-Murawska) [35]. Також система торговельного обслуговування населення у складі соціальної інфраструктури, сфери обслуговування розглядалася у роботах М. Барановського [1], С. Жовнір [7], І.Запотоцької[8], Ю. Зеленюк[9], О. Корнус, К. Нємець, Л. Нємець, А. Корнус [12], Б. Дале, П. Сьохольт (B. Dale, P. Sjoholt) [29], Д. Соколовскі (D. Sokolowski) [33], Я. Спілкової (J. Spilkova) [34] та інших вчених. Вищезгаданими науковцями досліджувалися різні регіони України, Росії, Молдови, Польща, Польщі, Чехії, Португалії, Норвегії. Окремі питання системи торговельного обслуговування населення Харківської області розкрито у роботі А.П. Голікова, Н.А. Казакової, М.В. Шуби [3], Стратегії розвитку Харківської області до 2020 року [24], Програмах економічного та соціального розвитку регіону [20], у Регіональній програмі удосконалення функціонування роздрібних ринків до 2016 року [21]. В програмах і стратегіях розвитку визначаються загальні проблеми розвитку, пропонуються шляхи їх вирішення, але переважно вони мають організаційний характер, розглядаються в економічній площині, не враховуються проблеми територіального характеру. Саме тому метою даною публікації виступає виявлення територіальних проблем розвитку системи торговельного обслуговування населення та розробка науково-обгрунтованих рекомендацій удосконалення цієї системи 3 позицій суспільної географії.

Виклад основного матеріалу. Для виявлення проблем розвитку системи торговельного обслуговування населення Харківської області було використано метод компонентного аналізу вектору розвитку, розроблений на кафедрі соціальноекономічної географії і регіонознавства Харківського національного університету імені В.Н. Каразіна [15]. Метод дозволяє проаналізувати динаміку окремих досліджуваних параметрів. Так, на кожний період часу параметру присвоюється код часової похідної - у разі збільшення показника код складає «+1», якщо залишається без змін - «0», при зменшенні показника - «-1». Потім розраховується сума кодів часових похідних за весь досліджуваний період.
Якщо показник зростає, це говорить про позитивні зрушення у розвитку певного явища, райони та міста використовують свої ресурси у повній мірі. Тенденції без змін свідчать про стабільність певного явища, процесу, які при прийнятті неправильних управлінських рішень можуть погіршуватися. Якщо показники зменшуються, це говорить про деградацію системи, в цьому проявляється проблема розвитку і на неї необхідно звертати увагу місцевим органам державної влади при плануванні своєї діяльності [15].

Більшість досліджуваних параметрів розглядаються як в абсолютному вимірі (фізична кількість об'єктів), так і у відносному (на душу населення, на площу території), що відображає ступінь забезпечення об'єктами роздрібної торгівлі, ресторанного господарства та їх територіальної доступності. Окремо слід зупинитися на динаміці зміни параметрів на душу населення. Якщо показник за досліджуваний період зростає, проте в абсолютному вимірі скорочується, це свідчить про більш уповільнене зменшення кількості закладів торгівлі, ресторанного господарства порівняно iз чисельністю населення (вона має тенденцію до скорочення в усіх районах та містах області). Динаміка без змін говорить про синхронне скорочення як чисельності об'єктів, так і населення, а динаміка скорочення - більш швидке зменшення кількості закладів торгівлі порівняно із чисельністю населення. Остання тенденція є загрозливою та потребує негайного вирішення.

Для виявлення проблем розвитку системи торговельного обслуговування населення Харківської області автором здійснено групування досліджуваних параметрів за наступними критеріями. Першим критерієм є визначення середньої динаміки зміни параметрів у розрізі районів та міст. Наприклад, якщо у більшості районів показник має позитивну динаміку, то він характеризується тенденцією зростання. Показники, що описуються в абсолютному та у відносному вимірах, також враховувалися при групуванні. Визначалася їх середня динаміка: якщо за трьома ознаками динаміка негативна - середня динаміка також негативна, а якщо одна ознака відмінна від інших (негативна або без змін), середня динаміка враховує більшість (тобто негативна динаміка). Другим критерієм є визначення середньої динаміки зміни параметрів за усіма районами та містами обласного підпорядкування, що засновано на розрахунку суми кодів часових похідних, тобто визначає середню тенденцію параметру по регіону в цілому. Як i в попередньому випадку, враховується динаміка параметру як в абсолютному, так і у відносному вимірах, визначається середня динаміка та середнє значення суми кодів часових похідних, що кількісно характеризує зміну параметрів. Велике значення суми кодів (позитивне або негативне) свідчить про певну стійку тенденцію зміни параметру у регіоні, а у разі наближення до 0 - переважання тенденції до змін, або нестабільної тенденції. Групування дає змогу визначити пріоритетність проблем та їх локальність. Проблеми, 
які мають місце для регіону в цілому, мають вирішуватися на регіональному рівні, локальні - на рівні місцевих громад (Таблиця 1).

Враховуючи вищезгадані критерії, автором виділено 5 груп параметрів. У I групу увійшли показники, які мали середню динаміку зміну параметру до зменшення як у розріз міст і районів, так і по регіону в цілому, у тому числі в абсолютному і відносному вимірах. II група включає параметри, які мають середню негативну динаміку зміни параметру як у розрізі районів, міст, так і по регіону в цілому, але на душу населення у деяких показників спостерігається зростання. III група складається 3 показників, для яких середня динаміка зміни параметру у розрізі районів $є$ незмінна, а в середньому по області - негативна. До IV групи увійшли параметри, які в середньому в переважній більшості районів, міст мають динаміку без змін, а по регіону в цілому - динаміка позитивна. V групу складають показники, які за усіма ознаками мають тенденцію зростання (таблиця 1). Розглянемо групи більш детально.

Так, у першу групу увійшли 20 показників, які характеризують демографічну ситуацію в регіоні, а також чисельність об'єктів роздрібної торгівлі. Практично в усіх адміністративно-територіальних одиницях спостерігалося скорочення закладів торгівлі, що є загрозливим для регіону в цілому, оскільки погіршується забезпеченість населення цими закладами та їх територіальна доступність. Скорочення напівстаціонарних об'єктів торгівлі обумовлено політикою місцевих органів державної влади щодо благоустрою території населених пунктів, боротьбою зі стихійною торгівлею, малими архітектурними формами та побудови/перебудови їх у сучасні торговельні павільйони. 3 одного боку, цей процес свідчить про підвищення культури ведення торговельної діяльності, 3 іншого, це зменшує доступність населення до торговельних об'єктів, особливо у міській місцевості, погіршує можливості ведення бізнесу. В цілому, скорочення магазинів, об'єктів ресторанного господарства обумовлено погіршенням фінансово-економічного стану підприємств внаслідок зниження купівельної спроможності населення, доходів громадян, загального скорочення чисельності населення, зростання кількості вибулих, що за своєю суттю є негативним явищем (також характерно для цієї групи), проте скорочення торговельних об'єктів відбувається більш швидкими темпами порівняно із динамікою чисельності населення. Дана тенденція буде продовжувати зростати, тому місцевим органам державної влади слід в першу чергу вжити заходів iз стимулювання зайнятості населення, підвищення купівельної спроможності населення, збільшеннях ïх доходів, сприяння збереженню торговельної мережі та відкриттю нових закладів, особливо у сільській місцевості, надання пільгових умов при державній реєстрації фізичних/юридичних осіб, державної підтримки в наданні мікрокредитів на започаткування власної справи, зниження обсягів оподаткування підприємств, надання пільг на орендну плату та на комунальні послуги, електроенергію, сприяння розвитку позамагазинної торгівлі, особливо у сільській місцевості.

До II групи відносяться 4 параметра: кількість місць для відвідувачів у закладах ресторанного господарства, їдалень, непродовольчих магазинів, спеціалізованих непродовольчих магазинів. Ці показники мають також негативну динаміку, але кількість закладів скорочується повільніше за чисельність населення, тому ситуація $є$ не такою загрозливою порівняно із динамікою параметрів попередньої групи, але при незмінності управлінських рішень ця тенденція буде погіршуватися. Проблеми повинні також вирішуватися на регіональному рівні, зокрема необхідно сприяти розвитку мережі непродовольчих магазинів, їдалень, впровадженню сучасних технологій ведення торгівлі, наданні пільгових умов підприємцям при відкритті власної справи, особливо у сільській місцевості, зменшенні податкового тиску на підприємців.

До III групи віднесені такі показники: кількість продовольчих, непродовольчих ринків, непродовольчих магазинів 3 універсальним асортиментом товарів, торгових місць та лотків на ринках, індекс товарообороту торгової мережі. У більшості районів області кількість продовольчих ринків не змінюється, проте в середньому по регіону можна стверджувати про негативну динаміку, що обумовлено нерентабельністю продажу виключно продовольчої продукції, внаслідок чого ринки трансформуються у змішані; крім того, супермаркети стають суттєвими гравцями на ринку продовольчих товарів. Враховуючи цю тенденцію, розроблено Програму удосконалення функціонування роздрібних ринків Харківської області на перспективу, відповідні районні програми, в яких передбачалося створення на ринках торгових місць на пільгових умовах, які будуть надаватися виробникам сільськогосподарської продукції, проведення продовольчих ярмарок, які підвищать питому вагу продовольчих товарів на ринках [21]. Програмою також було передбачено боротьбу зі стихійною торгівлею, реконструкцію ринків, створення торговельних павільйонів, що пояснює зменшення торгових місць, лотків на ринках [21]. Але такі трансформації на ринках, як вже зазначалося, свідчать про підвищення культури торговельного обслуговування населення. Непродовольчі ринки характеризуються стабільною динамікою. Індекс товарообороту торгової мережі розраховується у порівняльних цінах і відображає реальну динаміку товарообороту, тому його негативна динаміка в середньому по регіону свідчить про скорочення товарообороту. Враховуючи незначні суми індексів кодів часових похідних для цих параметрів, проблеми можна ідентифікувати як помірно-загрозливі, їх вирішення полягає у підвищенні рівня доходів громадян, зменшенні податкового навантаження, продовженні проведення ярмаркових заходів, акційних заходів власниками великих торговельних мереж, які дають змогу продавати сільськогосподарську продукцію і11 виробниками, товари у супермаркетах за зниженими 
Таблиия 1. Групування параметрів, що характеризують систему торговельного обслуговування населення за динамікою їх змін (складено автором за даними $[18,22,28])$

\begin{tabular}{|c|c|c|c|c|c|c|c|c|c|c|c|}
\hline \multirow{2}{*}{$\begin{array}{l}\text { 营 } \\
\text { 点 }\end{array}$} & \multirow[t]{2}{*}{ Параметри } & \multicolumn{4}{|c|}{\begin{tabular}{l} 
Динаміка роз- \\
витку параметрів \\
за сумою індексів \\
кодів часових \\
похідних у роз- \\
різі районів та \\
міст обласного \\
підпорядкування \\
\multicolumn{2}{c}{ за весь період }
\end{tabular}} & \multicolumn{4}{|c|}{\begin{tabular}{lr} 
Динаміка & роз- \\
витку параметрів \\
за сумою \\
кодів & часоксів \\
похідних & по \\
регіону в цілому & \multicolumn{2}{c}{ за весь період }
\end{tabular}} & & \multirow[t]{2}{*}{$\begin{array}{c}\text { Характер проблем та напрями ї } \\
\text { вирішення }\end{array}$} \\
\hline & & 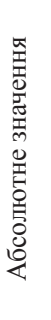 & 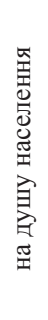 & 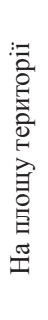 & 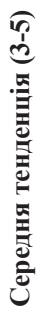 & 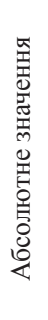 & 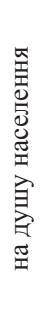 & 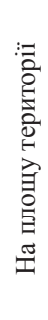 & 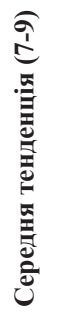 & 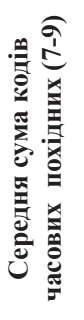 & \\
\hline 1 & 2 & 3 & 4 & 5 & 6 & 7 & 8 & 9 & 10 & 11 & 12 \\
\hline \multirow{20}{*}{ I } & Чисельність населення & - & & & - & - & & & - & -175 & \multirow{20}{*}{$\begin{array}{l}\text { Проблеми мають регіональний } \\
\text { характер. Скорочення кількості } \\
\text { закладів ресторанного господарства, } \\
\text { погіршення забезпеченості населення } \\
\text { ними, територіальної доступності на } \\
\text { фонізагальногоскороченнячисельності } \\
\text { населення буде продовжуватися при } \\
\text { незмінності управлінських рішень. } \\
\text { Ця тенденція є загрозливою, тому } \\
\text { проблеми потребують вирішенн } \\
\text { у першу чергу. Місцевим органам } \\
\text { державної влади необхідно вжити } \\
\text { заходів із стимулювання зайнятості } \\
\text { населення, створення нових робочхх } \\
\text { місць, збереження існуючої мережі } \\
\text { закладів та відкиитя нових, } \\
\text { підвищення купівельної спроможності } \\
\text { населення, зменшення податкового } \\
\text { навантаження на бізнес. }\end{array}$} \\
\hline & Чисельність сільського населення & - & & & - & - & & & - & -162 & \\
\hline & Щільність сільського населення & - & & & - & - & & & - & -158 & \\
\hline & Щільність міського населення & - & & & - & - & & & - & -149 & \\
\hline & Чисельність міського населення & - & & & - & - & & & - & -148 & \\
\hline & Кількість найманих працівників & - & - & & - & - & - & - & - & -89 & \\
\hline & Питома вага сільського населення & - & & & - & - & - & & - & -89 & \\
\hline & Кількість об’єктів роздрібної торгівлі & - & - & - & - & - & - & - & - & -69 & \\
\hline & Кількість продовольчих магазинів & - & - & - & - & - & - & - & - & -65 & \\
\hline & Щільність населення & - & - & - & - & - & - & - & - & -65 & \\
\hline & Кількість вибулих (негативний показник) & + & + & + & + & + & + & + & + & 58 & \\
\hline & Кількість магазинів роздрібної торгівлі & - & - & - & - & - & - & - & - & -53 & \\
\hline & $\begin{array}{l}\text { Кількість продовольчих } \\
\text { спеціалізованих магазинів }\end{array}$ & - & - & - & - & - & - & - & - & -48 & \\
\hline & Кількість кафе, закусочних & - & - & - & - & - & - & - & - & -47 & \\
\hline & Кількість прибулих & - & - & - & - & - & - & - & - & -42 & \\
\hline & $\begin{array}{ll}\text { Кількість напівстаціонарних } & \text { об’єктів } \\
\text { роздрібної торгівлі } & \\
\end{array}$ & - & - & - & - & - & - & - & - & -39 & \\
\hline & Кількість об’єктів поза магазинами & - & - & - & - & - & - & - & - & -38 & \\
\hline & $\begin{array}{lll}\text { Кількість } & \text { об’єктів } & \text { ресторанного } \\
\text { господарства }\end{array}$ & - & - & - & - & - & - & - & - & -36 & \\
\hline & $\begin{array}{l}\text { Кількість продовольчих магазинів } \\
\text { універсальним асортиментом товарів }\end{array}$ & - & - & - & - & - & - & - & - & -33 & \\
\hline & Кількість аптечних пунктів & - & - & - & - & - & - & - & - & -5 & \\
\hline \multirow[b]{4}{*}{ II } & $\begin{array}{c}\text { Кількість місць для відвідувачів у } \\
\text { закладах ресторанного господарства }\end{array}$ & - & + & - & - & - & + & - & - & -11 & \multirow{4}{*}{$\begin{array}{l}\text { Проблеми регіонального характеру. } \\
\text { Скорочення кількості непродовольчих } \\
\text { магазинів, їдалень, місць для } \\
\text { відвідувачів у закладах ресторанного } \\
\text { господарства також буде надалі } \\
\text { продовжуватися, якщо управлінські } \\
\text { рішення не будуть коригуватися. Але } \\
\text { ця тенденція є не такою загрозливою, } \\
\text { оскільки на душу населення дані } \\
\text { параметри зростають, що свідчить } \\
\text { про більш уповільнене зменшення } \\
\text { закладів у порівнянні з темпами } \\
\text { скорочення чисельності населення. } \\
\text { Проблеми повинні вирішуватися на } \\
\text { регіональному рівні, зокрема необхідно } \\
\text { вживати заходів щодо збереження } \\
\text { існуючої кількості непродовольчих } \\
\text { магазинів, їдалень, надання пільгових } \\
\text { умов підприємцям для відкриття } \\
\text { власної справи, особливо у сільській } \\
\text { місцевості. Проблеми мають другий } \\
\text { пріоритет вирішення. }\end{array}$} \\
\hline & Кількість їдалень & - & + & - & - & - & + & - & - & -8 & \\
\hline & Кількість непродовольчих магазинів & - & - & - & - & - & + & - & - & -6 & \\
\hline & $\begin{array}{c}\text { Кількість непродовольчих спеціалізованих } \\
\text { магазинів }\end{array}$ & - & - & - & - & - & + & - & - & -4 & \\
\hline
\end{tabular}




\begin{tabular}{|c|c|c|c|c|c|c|c|c|c|c|c|}
\hline \multirow[b]{6}{*}{ III } & Кількість продовольчих ринків & 0 & 0 & 0 & $\mathbf{0}$ & - & 0 & - & - & -12 & \multirow{6}{*}{ 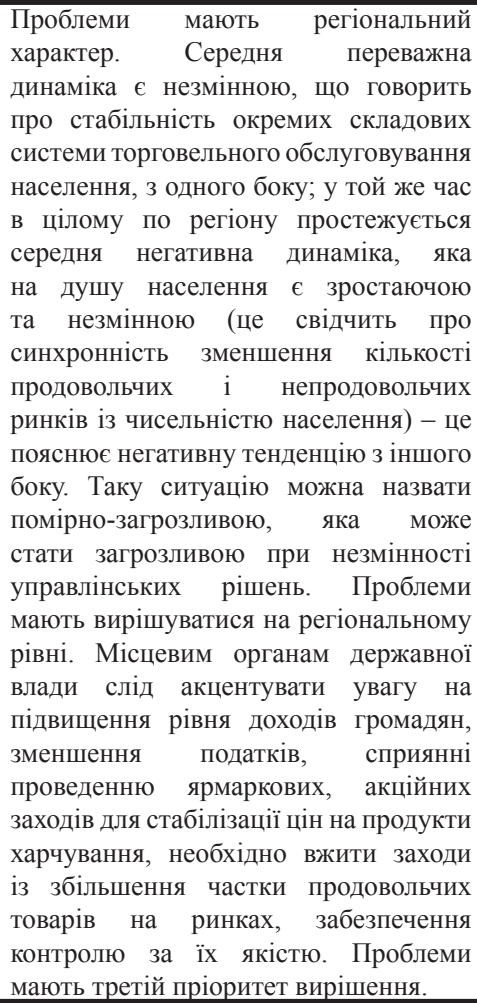 } \\
\hline & Індекс товарообороту торгової мережі & 0 & & & $\mathbf{0}$ & - & & & - & -9 & \\
\hline & Кількість лотків на ринках & 0 & 0 & 0 & $\mathbf{0}$ & - & + & - & - & -2 & \\
\hline & Кількість непродовольчих ринків & 0 & 0 & 0 & $\mathbf{0}$ & - & 0 & - & - & -1 & \\
\hline & $\begin{array}{l}\text { Кількість непродовольчих магазинів } 3 \\
\text { універсальним асортиментом товарів }\end{array}$ & 0 & 0 & 0 & $\mathbf{0}$ & - & + & - & - & 1 & \\
\hline & Кількість торгових місць на ринках & 0 & + & 0 & $\mathbf{0}$ & - & + & - & - & 18 & \\
\hline \multirow[b]{8}{*}{ IV } & $\begin{array}{c}\text { Індекс товарообороту підприємств } \\
\text { ресторанного господарства }\end{array}$ & 0 & & & $\mathbf{0}$ & + & & & + & 2 & \multirow{8}{*}{$\begin{array}{l}\text { Проблеми локального } \\
\text { Середня парактеру. } \\
\text { є незмінною, що свідчить про } \\
\text { стабільність окремих складових } \\
\text { системи торговельного обслуговування } \\
\text { населення, але в регіоні в цілому } \\
\text { спостерігається динаміка зростання, } \\
\text { що говорить про позитивні зрушення } \\
\text { у певних складових системи в регіоні. } \\
\text { Дану тенденцію слід контролювати. } \\
\text { Але в окремих адміністративно- } \\
\text { територіальних одиницях прослід- } \\
\text { ковується негативна динаміка } \\
\text { зазначених параметрів, яка може } \\
\text { у майбутньому погіршитися. Тому } \\
\text { вирішувати ці проблеми необхідно } \\
\text { на рівні окремих територіальних } \\
\text { громад, зокрема сприяти збереженню } \\
\text { кількості барів, ресторанів, особливо } \\
\text { акцентувати увагу на підвищенні } \\
\text { доходів населення, вживати заходи } \\
\text { щодо стабілізації цінової ситуації } \\
\text { на товари першої необхідності. } \\
\text { Проблемам присвоюється четвертий } \\
\text { пріоритет вирішення. }\end{array}$} \\
\hline & Кількість барів & 0 & 0 & 0 & $\mathbf{0}$ & + & + & + & + & 2 & \\
\hline & Кількість ринків & 0 & 0 & 0 & $\mathbf{0}$ & + & + & + & + & 5 & \\
\hline & Кількість ресторанів & 0 & 0 & 0 & $\mathbf{0}$ & + & + & + & + & 5 & \\
\hline & Торгова площа ринків & 0 & + & 0 & $\mathbf{0}$ & 0 & + & + & + & 6 & \\
\hline & Кількість магазинів на ринках & 0 & 0 & 0 & $\mathbf{0}$ & + & + & + & + & 12 & \\
\hline & Кількість змішаних ринків & 0 & 0 & 0 & $\mathbf{0}$ & + & + & + & + & 19 & \\
\hline & Кількість аптек & 0 & 0 & 0 & $\mathbf{0}$ & + & + & + & + & 21 & \\
\hline \multirow{12}{*}{ V } & Оптовий товароооборот & + & + & + & $\overline{+}$ & $\overline{+}$ & + & + & $\bar{T}$ & 4 & \multirow{12}{*}{$\begin{array}{l}\text { Проблеми мають локальний характер. } \\
\text { Динаміка параметрів є позитивною, ця } \\
\text { тенденція буде продовжуватися. Проте } \\
\text { у деяких містах та районах області } \\
\text { спостерігається погіршення стану явищ } \\
\text { порівняно із загальною позитивною } \\
\text { динамікою у регіоні в цілому. Якщо на } \\
\text { цю тенденцію не звертати уваги, вона } \\
\text { буде погіршуватися та стане загрозли- } \\
\text { воювокремихрайонах.Проблеми мають } \\
\text { бути вирішені місцевими органами } \\
\text { державної влади, зокрема необхідно } \\
\text { сприяти підвищенню купівельної } \\
\text { спроможності населення, зростанню } \\
\text { доходів громадян, підприємницькій } \\
\text { діяльності, стимулювати місцевих } \\
\text { товаровиробників у нарощуванні } \\
\text { продукції та ії реалізації, пошуку } \\
\text { джерел інвестицій у підприємства } \\
\text { районів. Проблемам надається } \\
\text { п’ятий пріоритет. }\end{array}$} \\
\hline & Сальдо міграції & + & + & + & + & + & + & + & + & 6 & \\
\hline & Кількість АЗС & + & + & + & + & + & + & + & + & 25 & \\
\hline & $\begin{array}{c}\text { Вантажооборот автомобільного } \\
\text { транспорту }\end{array}$ & + & + & + & + & + & + & + & + & 32 & \\
\hline & Кількість суб’єктів ЄДРПОУ & + & + & + & + & 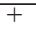 & + & + & + & 44 & \\
\hline & Кількість кіосків, контейнерів на ринках & + & + & + & + & + & + & + & + & 46 & \\
\hline & Природний приріст & + & + & + & + & + & + & + & + & 46 & \\
\hline & Рівень урбанізації & + & + & + & + & + & + & + & + & 71 & \\
\hline & $\begin{array}{c}\text { Роздрібний товарооборот підприємств } \\
\text { ресторанного господарства }\end{array}$ & + & + & + & + & + & + & + & + & 81 & \\
\hline & Роздрібний товарооборот торгової мережі & + & + & + & + & + & + & + & + & 126 & \\
\hline & $\begin{array}{l}\text { Роздрібний товарооборот підприємств, у } \\
\text { т.ч. ресторанного господарства }\end{array}$ & + & + & + & + & + & + & + & + & 127 & \\
\hline & $\begin{array}{c}\text { Середньомісячна заробітна плата } \\
\text { працівників } \\
\end{array}$ & + & + & + & + & + & + & + & + & 196 & \\
\hline
\end{tabular}


цінами. Також необхідно вживати заходів стосовно збільшення частки продовольчих товарів на ринках, контролю їх якості, зниження орендної плати за користування торговими місцями на ринках.

В IV груnу включені наступні показники індекс товарообороту підприємств ресторанного господарства, кількість барів, ринків, ресторанів, магазинів на ринках, змішаних ринків, аптек, торгова площа ринків. Дані параметри характеризуються відносною стабільністю, оскільки у більшості адміністративно-територіальних одиниць регіону динаміка без змін, а в середньому по регіону позитивна, що говорить про використання наявних ресурсів в регіоні у повній мірі. Тому така тенденція не викликає особливих занепокоєнь, але потребує контролю з боку місцевих органів державною влади. У той же час є райони та міста в області, для яких характерне скорочення цих показників протягом досліджуваного періоду:

- індекс товарообороту підприємств ресторанного господарства - Барвінківський, Вовчанський, Куп'янський, Сахновщинський, Харківський райони;

- кількість аптек - Вовчанський, Дворічанський, Дергачівський, Красноградський, Куп'янський, Первомайський, Печенізький, Харківський райони);

- торгова площза ринків - Зміївський, Краснокутський, Харківський райони, м. Ізюм;

- $\quad$ кількість ринків - Зачепилівський, Зміївський райони;

- кількість змішаних ринків - Зміївський, Нововодолазький райони;

- кількість магазинів на ринках - м. Лозова;

- кількість ресторанів - Борівський, Ізюмський райони;

- кількість барів - Богодухівський, Великобурлуцький, Борівський, Ізюмський, Чугуївський райони, м. Лозова.

Проблеми мають локальний характер, тому місцевим органам державної влади згаданих адміністративно-територіальних одиниць необхідно здійснювати коригування управлінських рішень, оскільки тенденція до зменшення може продовжуватися. Потребує здійснення заходів щодо зростання купівельної спроможності населення, розвитку мережі барів, ресторанів, аптек, надання мікрокредитів, пільгових умов при відкритті та веденні бізнесу, зниження вартості оренди, інших платежів за користування торговими місцями на ринках, що дасть змогу збільшити кількість магазинів на ринках.

$V$ група включає 12 показників, які характеризують загальний соціально-економічний розвиток та товарооборот підприємств. Ці параметри зростають як в цілому по регіону, так і у розрізі міст, районів. Зростання оптового, роздрібного товарообороту (показники розраховуються у фактичних цінах), середньомісячної заробітної плати обумовлено інфляцією, яка кожного року зростає. Проте у деяких районах спостерігається скорочення обсягів роздрібного товарообороту торгової мережі (Ізюмський район), підприємств ресторанногогосподарства(Вовчанський, Ізюмський, Краснокутський райони), оптового товарообороту (Балаклійський, Богодухівський, Валківський, Вовчанський, Дворічанський, Зачепилівський, Зміївський Кегичівський, Краснокутський, Первомайський, Шевченківський райони, м. Лозова, м. Первомайський). Така тенденція свідчить про загрозливу ситуацію стосовно роздрібного товарообороту у вищезгаданих районах, оскільки він переважно скорочується на фоні загального зростання. Проблеми мають локальний характер, тому необхідно вживати дій 3 покращення купівельної спроможності населення, зростання його доходів, стимулювання місцевих виробників до збільшення обсягів виробництва та реалізації продукції.

Зменшується кількістьАЗСуВеликобурлуцькому, Зачепилівському, Коломацькому, Первомайському районах, м. Люботин, м. Первомайський, кількість контейнерів, кіосків на ринках - у Валківському, Кегичівському районах, м. Куп'янську, кількість суб'єктів ЄДРПОУ - у Зачепилівському, Коломацькому районах, м. Ізюм, м. Куп'янск, м. Лозова, м. Люботин, вантажооборот автомобільного транспорту - у Барвінківському, Борівському, Зачепилівському, Ізюмському, Сахновщинському районах, м. Ізюм. Тому місцевим органам державної влади необхідно акцентувати увагу на розвитку i збереженні існуючої мережі АЗС, сприяти розвитку підприємництва, надавати консультації населенню 3 започаткування власної справи, здійснювати пошук джерел інвестування у підприємства районів.

Висновки. Таким чином, метод компонентного аналізу вектору розвитку дозволяє оцінити динаміку окремих досліджуваних параметрів системи торговельного обслуговування населення. Відповідно до характеру переважаючої динаміки розвитку параметрів серед районів та міст обласного підпорядкування та загальної динаміки по регіону в цілому виділено 5 груп параметрів. Зменшення параметру протягом досліджуваного періоду $\epsilon$ базисом виявлення проблем розвитку, визначення їх як регіональних або локальних, пріоритетності вирішення. Перші три групи характеризують регіональні проблеми, оскільки середня переважаюча тенденція $€$ негативною та залишається без змін, а середня регіональна динаміка характеризується зменшенням. Дві останні групи визначають локальні проблеми, оскільки на регіональному рівні середня переважна тенденція $\epsilon$ позитивною та залишається без змін, середня регіональна динаміка характеризується зростанням, проте на рівні окремих адміністративно-територіальних одиниць Харківської області спостерігається динаміка зменшення. Такий підхід дозволяє розробляти рекомендації місцевим органам державної влади стосовно напрямків їх подальшої діяльності, пріоритетності вирішення проблем, враховуючи територіальні особливості розвитку системи торговельного обслуговування населення регіону. 


\section{References:}

1. Baranovskij N.A. Territorial'naâ organizaciâ peredvižnyh form obsluživaniâ sel'skogo naseleniâ Černigovskoj oblasti [Territorial organization of mobile services for rural population in Chernihiv region]: Extended abstract of PhD thesis: specialty 11.00.02 - Economic and social geography, Kyiv, 1992, 22 p. (in Russian).

2. Bìlokìn' T.G. Regulûvannâ rozvitku regional'nogo spoživčogo rinku [Regulation for the regional consumption market development]: extended abstract of PhD thesis. Cherkasy, 2012, 20 p. (in Ukrainian).

3. Golikov A.P., Kazakova N. A., Šuba M. V. Har 'kovskaâ oblast'. Regional'noe razvitie: sostoânie i perspektivy [Kharkiv region. Regional development, state and perspectives]. Kharkiv, 2012, 223 p. (in Russian).

4. Golovnâ O.M. Regional'ni osoblivostì rozvitku torgovo-pobutovoï sferi [Regional features of the development commercial and household sphere]: extended abstract of PhD thesis. Kyiv, 2007, 20 p. (in Ukrainian).

5. Grigor'eva M.A. Territorial'nye osobennosti razvitiâ rozničnoj torgovli v usloviâh èkonomičeskih reform (na primere Irkutska) [Territorial features of the development retail trade in conditions of economic reforms (illustrated by Irkutsk): extended abstract of PhD thesis. Irkutsk, 2004, 22 p. (in Russian).

6. Dorošenko V.Ì. Teritorial'na organizaciâ spoživčogo kompleksu v regional'nih ì lokal'nih sistemah rozselennâ [Territorial organization of the consumption complex in local resettlement systems]: extended abstract of PhD thesis: spec.: 11.00.02 «Ekonomična ta social'na geografîa», K., 1994, 25 p. (in Ukrainian).

7. Žovnìr S.M. Suspil'na ta teritorìal'na organizaciâ sferi poslug regìonu v umovah rinkovoï transformacï (na prikladì Vìnnic'koï oblastì) [Societal and territorial organization of the regional service sector in conditions of market transformations]: extended abstract of PhD thesis. Kyiv, 2008, 21 p. (in Ukrainian).

8. Zapotoc'ka İ.V. Teritorial'vnì naprâmki ï̈ vdoskonalennâ [Territorial organization of social sphere in cherkasy region and the main directions of its improvement]: extended abstract of PhD thesis. Kyiv, 2007, $21 \mathrm{p}$. (in Ukrainian).

9. Zelenûk Û.M. Territorial'naâ organizaciâ social'noj infrastruktury v Irkutsko-Čeremhovskom èkonomičeskom rajone [Territorial organization of social infrastructure in Irkutsk-Cheremhovsky economic district]: extended abstract of PhD thesis. Irkutsk, 2006, 22 p. (in Russian).

10. Kalmuskaâ Ė.I. Opyt geografičeskogo izučeniâ potrebleniâ material'nyh blag naseleniâ Moldavskoj SSR [Experience of geographical study: consumption of material benefits in the Moldavian SSR]: extended abstract of PhD thesis. Kyiv, 1974, 23 p. (in Russian).

11. Kolosìns'kij Ê.Û. Transformaciâ teritorial'noï organìzacï torgovel'noï sferi regionu v umovah rozvitku postindustrial'nö̈ ekonomiki [Transformation territorial organization of trade sphere of a region in conditions of development postindustrial economics] : extended abstract of $\mathrm{PhD}$ thesis. Užgorod, 2012, 20 p. (in Ukrainian).

12. Kornus O.G. Sfera obslugovuvannâ naselennâ Sums 'koï oblastì: suspill'no-geografični aspect [Public service sector of Sumy region: human-geographical aspects]. Kharkiv, 2009, 225 p. (in Ukrainian).

13. Mal's'ka M.P. Regìnal'nì osoblivostì formuvannâ ì rozvitku torgovel'nogo kompleksu oblastì [Regional features of formation and development of the regional trade complex]: extended abstract of PhD thesis. Lviv, 1993, 20 p. (in Ukrainian).

14. Mamčur O.Ì. Suspil'no-geografični problemi formuvannâ rinkovoï infrastrukturi L'vivs 'koï oblasti [Humangeographical problems of formation market infrastructure in Lviv region]: extended abstract of PhD thesis. Lviv, 2010, 21 p. (in Ukrainian).

15. Nêmec' K., Gruška V. Komponentnij analìz vektoru rozvitku socìogeosistem [Component analysis of the vector development of socio-geographical systems]. Journal of Human Geography, 2014, Vol. 16 (1), pp. 7-15. (in Ukrainian)

16. Nikol'skij I.V. Izbrannye Trudy [Selected works]. Smolensk, Ojkumena, 2009, 332 p. (in Russian).

17. Osìpčuk İ.O. Teritorìal'na organizaciâ torgovel'nogo obslugovuvannâ naselennâ Rìnens'kö̈ oblastì [Territorial organization of population trade service in Rivne region]: extended abstract of PhD thesis. Kyiv, 2013, 20 p. (in Ukrainian).

18. Official web-site of Kharkiv Regional State Administration. Access mode: http:// www.kharkivoda.gov.ua

19. Pahomov V.Ì. Optimìaciâ strukturi ta rozmisennâ rozdribnoï torgovoï mereži v najbil'ših mistah [Optimization structure and placement of the retail trade network in the biggest cites]: extended abstract of PhD thesis. Kyiv, 1993, 18 p. (in Ukrainian).

20. Programa ekonomičnogo ì social'nogo rozvitku Harkivs 'koï oblastì na 2016 rìk [Program of economic and social development of Kharkiv region on 2017]. (in Ukrainian).

21. Regional'na programa vdoskonalennâ funkcionuvannâ rozdribnih rinkìv do 2016 r. [Regional program of improvement functioning retail markets till 2016]. (in Ukrainian).

22. Rozdrìbna torgìvlâ Harkivs 'kö̈ oblastì u 2015 rocì: statističnij ŝoričnik [Retail trade in Kharkiv region in 2015 : Statistical yearbook], Ed.: O.V. Vlasova. Kharkiv, 2014, 98 p. (in Ukrainian)

23. Social'nij rozvitok Ukraïni: sučasni transformaciï ta perspektivi [Social development of Ukraine: modern transformations and perspectives]. Ed. S.İ. Bandur, T.A. Zaâc', V.İ. Kucenko ta ìn., K., Brama-Ukraïna, 2006,758 p. (in Ukrainian)

24. Strategiâ rozvitku Harkìvs 'koï oblastì na perìod do 2020 roku [Development strategy of Kharkiv region till 2020] (in Ukrainian).

25. Ukolova I.I. Territorial'nâ̂ organizaciâ torgovli Voronežskoj oblasti v perehodnoj èkonomike [Territorial 
organization of trade in Voronez region in transition economy]: extended abstract of $\mathrm{PhD}$ thesis. Voronezh, 2005, $22 \mathrm{p}$. (in Ukrainian).

26. Ûrčenko S. A. Infrastruktura mira [The world infrastruture]. Kharkiv, 2006, 328 p. (in Russian).

27. Šenceva L. N. Territorial'naâ organizaciâ potrebitel'skoj kooperacii Voronežskoj obasti [Territorial organization of consumer cooperation Voronez region]: extended abstract of PhD thesis. Voronezh, 2005, 21 p. (in Russian)

28. Harkivs'ka oblast' u 2015 rocì: statističnij soričnik [Kharkiv region in 2015: statistical yearbook], Ed. O.G. Mamontova, 2016, CD-ROM. (in Ukrainian).

29. Dale B., Sjoholt P. The changing structure of the central pace system in Trondelag, Norway, over the past 40years - viewed in the light of old and recent theories and trends. Geografiska Annaler: Series B, Human Geography, 2007, Vol. 89, issue Supplement s1, pp. 13-30.

30. Dudek-Mańkowska S. Shopping centres in the Warsaw Metropolitan Area. Acta Unversitatis Carolinae Geographica. Praha, Charles University, 2010, Vol. 45, No 1, pp. 35-47.

31. Fellmann J., Getis A., Getis J. Human geography: landscapes of human activities. Boston; Burr Ridge; Dubuque etc., McGraw-Hill Higher Education, 2003, 573 p.

32. Guimaraes P.P. The prospective impact of new shopping centres on the retail structure of Braga. Bulletin of Geography. Socio-economic series. Torun, Nicolaus Copernicus University, 2014, №25, pp. 167-180.

33. Sokolowski D. Changes of service structure in Polish cities during system transformation. Bulletin of Geography. Socio-economic series. Torun, Nicolaus Copernicus University, 2005, N. 4, pp. 183-190.

34. Spilkova J. Foreign frms and their perception of region in the Czech Republic: manufacturing industry versus producer services. Acta Unversitatis Carolinae Geographica, 2010, Vol. 1-2, pp. 109-122.

35. Szymańska D., Środa-Murawska S. Central and Eastern Europe in the light of the spatial distribution of luxury stores - some problems. Journal of Human Geography, 2013, Vol. 15 (2), pp. 48-56. 